\title{
Trust School Standards and Practices Measurement Instrument: Validity and Reliability
}

\author{
Norazila Osman, Kamarul Bahari Yaakub
}

To Link this Article: http://dx.doi.org/10.6007/IJARBSS/v12-i1/12354

DOI:10.6007/IJARBSS/v12-i1/12354

Received: 14 November 2021, Revised: 16 December 2021, Accepted: 10 January 2022

Published Online: 28 January 2022

In-Text Citation: (Osman \& Yaakub, 2022)

To Cite this Article: Osman, N., \& Yaakub, K. B. (2022). Trust School Standards and Practices Measurement Instrument: Validity and Reliability. International Journal of Academic Research in Business and Social Sciences, 12(1), 2749-2759.

\section{Copyright: (c) 2022 The Author(s)}

Published by Human Resource Management Academic Research Society (www.hrmars.com)

This article is published under the Creative Commons Attribution (CC BY 4.0) license. Anyone may reproduce, distribute, translate and create derivative works of this article (for both commercial and non0-commercial purposes), subject to full attribution to the original publication and authors. The full terms of this license may be seen at: http://creativecommons.org/licences/by/4.0/legalcode

\section{Vol. 12, No. 1, 2022, Pg. $2749-2759$}

Full Terms \& Conditions of access and use can be found at http://hrmars.com/index.php/pages/detail/publication-ethics 


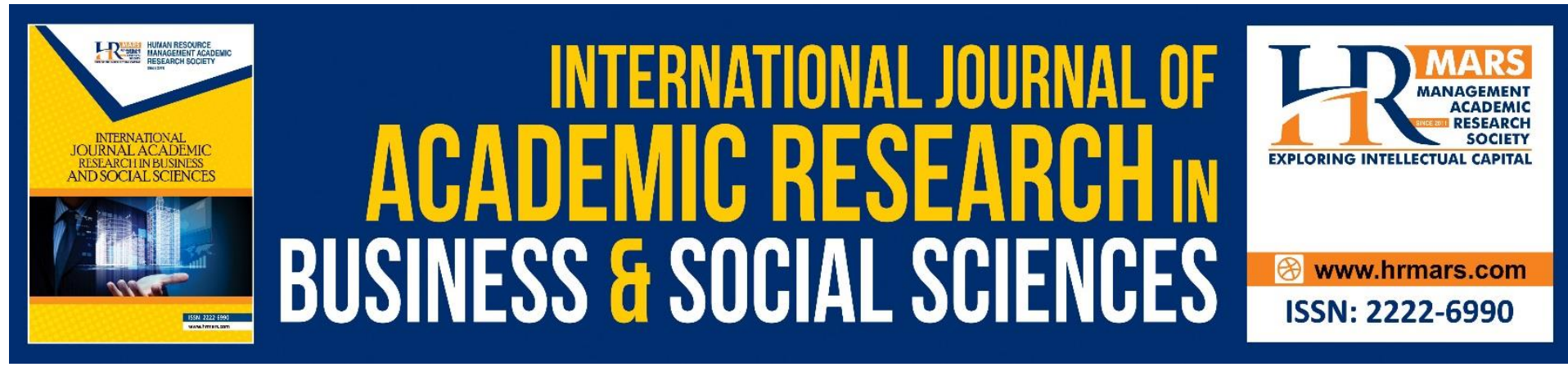

\title{
Trust School Standards and Practices Measurement Instrument: Validity and Reliability
}

\author{
Norazila Osman, Kamarul Bahari Yaakub \\ Faculty of Management and Economics, Tanjung Malim, Malaysia
}

\begin{abstract}
The Trust School Programme is a national level education transformation programme that aims to encourage the involvement of private sectors in efforts to boost the quality of national education through the improvement of school management system, educational delivery methods, and teaching and learning environment in schools. There are four standards forming the framework of this programme known as Trust School Standards and Practices (TSSP). However, research on TSSP is less conducted than the research on Educational Quality Practice Standards. Therefore, this study aims to develop and validate a measurement instrument that can be used to measure the effectiveness of TSSP implementation in all Trust Schools in Malaysia. This instrument was developed based on Systems Theory by Ludwig Von Bertalanffy and adapted from the Malaysian Education Quality Standard Wave 2 (SKPMg2) to measure the TSSP constructs. The instrument was assessed by six experts for its validity. The score given by the experts to each item was accumulated and analysed using Content Validity Index. The result of the analysis showed that, the total value of all items was high with an expert agreement percentage of $90.3 \%$. This study involved 100 teachers from three Trust Schools in Perak and Terengganu. Data from the questionnaires were then processed using IBM SPSS software to determine the level of reliability of the questionnaire items through internal consistency method. The Alpha Cronbach's value obtained was above 0.85 which was high.This study has proven that this instrument is capable in measuring the effectiveness of Trust School Standards and Practices in Malaysian Trust Schools.
\end{abstract}

Keywords: TSSP, Validity, Reliability

\section{Introduction}

Education is an important aspect in nation building that contributes to social and economic development (Lu, 2018). The World Bank (2018) has reported that the world is currently facing a learning crisis that can affect outcomes in education. Surprisingly, studies on educational quality standards in schools (Jiali et al., 2019; Ajayi \& Oyeniyi, 2017) remain scant (Scheiler, 2018; Sfakianaki, 2018).

Educational quality standards generally cover systems and processes of meeting the needs of students and the goals of educational organization (Hashim, 2018). Educational quality standards also promote the improvement of quality in teaching and learning as well 
as students' academic well-being (Akhtar et al., 2014; Jiali et al., 2019). As such, awareness of quality in education is now a major focus nationwide (Garira et al., 2020).

The Ministry of Education Malaysia (MOE) is concerned about quality education agenda. Therefore, MOE has taken steps to improve the existing education system to a quality education system to improve outcomes and boost students' achievement as desired locally and globally (MOE, 2016; Noredayu et al., 2016) by implementing transformation in education. On that point, the drafting of PPPM (2013-2025) began.

Along with the 9th and 10th shifts of PPPM (2013-2025), MOE has established Trust School Programme (TSP) to achieve the aspirations and targets of educational transformation. TSP is an educational transformation programme at the national level implemented specifically through public-private partnerships. The main purpose of this programme is to encourage the involvement of the private sector in efforts to boost the quality of national education through the improvement of school management systems, educational delivery methods and teaching and learning environment in government schools and government aided schools. The main outcome of this programme is improvement in students' achievement in line with the students' aspirations in PPPM 2013-2025. The purpose of this programme is to maximize students' outcomes to ensure the national education sector produce highly skilled human resources with leadership characteristics to drive the national economic sector, thus becoming a catalyst for overall change in human capital development in the country (MOE, 2016 ).

However, the implementation of Educational Quality Standards and Practices is becoming a new challenge in the field of education (Jiali et al., 2019). In terms of Trust School Standards and Practices (TSSP), it reckons the concept of 21st Century Learning which is more flexible, challenging and creative towards improving the quality of learning in Malaysia. TSSP provides a framework to all Trust Schools to ensure success can be achieved at every phase. TSSP consists of four standards with 20 indicators describing practices related to competencies of school leaders, teachers, students, systems and values in order to achieve the goal of students' outcomes and well -being. However, the effectiveness of TSSP implementation in Malaysian Trust Schools cannot be ascertained due to lack of studies on Trust Schools in general and TSSP in particular. Therefore, this study aims to develop and validate an instrument that can be used to measure the effectiveness of TSSP implementation in all Trust Schools in Malaysia. This measurement instrument was developed based on Systems Theory by Ludwig Von Bertalanffy (1968) and adapted from the Malaysian Education Quality Standard Wave 2 (SKPMG2) to measure the TSSP constructs.

The purpose of this study was to determine the validity and reliability of Trust School Standards and Practices measurement instrument. Specifically, the objectives of the study are to determine the suitability of the instrument items through expert validation and the reliability of the instrument items through Cronbach Alpha coefficient analysis.

\section{Literature Review}

The struggle to uphold quality education in our country has never stopped. This is evident through massive education transfromation by the Ministry of Education Malaysia in Pelan Pembangunan Pendidikan Malaysia (PPPM) 2013-2025. PPPM was developed to evaluate the performance of the national education system by taking into account previous achievements in education and comparing them with international benchmarks (PPPM 2013-2025). In accordance to the decline of Malaysian students' achievement in PISA and TIMSS international assessments, MOE has implemented a review on the national education system 
to be redeveloped into a new Education Development Plan with a vision to improve students' performance to be in line with international education standards (MOE, 2016).

The Trust School Programme (TSP) is an initiative that aims to directly support the vision and aspirations of the MOE. TSP is developed and designed by taking into account the views and feedback from various stakeholders in education. The programmes planned in TSP are in line with the goal of PPPM 2013-2025 which is to boost the quality of education in Malaysia through five aspirations of the system; quality, equity, unity and efficiency.

There have been several reviews, reforms of the structure and function of education developed using approaches in Educational Quality Standards and Practices (Cruz et al., 2016; Pourrajab et al., 2007; Sunder, 2016). However, there is little skepticism about the effectiveness of Standards and Practices to boost the quality in education as a whole (Law, 2010; Quinn, 2009; Venkatraman, 2007). This statement was acknowledged by Sonia-Garcia and Martinez-Lorente (2014) who stated that there were very few studies on Standards and Educational Quality Practices. As a result, the literature review on Educational Quality Standards and Practices in general and TSSP in particular (Trust School Standard Procedures/ TSSP) are quite limited.

At present, the level of school excellence in Malaysia is evaluated through the Malaysian Education Quality Standard Wave 2 (SKPMg2) instrument which is the main mechanism for evaluating Malaysian education quality standards. SKPMg2 was designed as a result of feedback and views of the top management of MOE, School Inspectorates, principals, headmasters, excellent teachers, expert teachers, teachers' unions, experts in the field of education from public universities, literature review, books and related documents on educational standards (Sathiyabama, 2017). The basic concept of SKPMg2 refers to Effective School Model (Mortimore, 1995) presented in the Roadmap of the Board of Inspectorates and Quality Assurance (JNJK) 2010 - 2025 whilst The Effective School Model is based on System Theory. In the context of the study, System Theory underpins TSSP because the principles in System Theory comply with the principles of TSSP itself. According to this theory, organizational goal is unattainable if the elements in the system do not complement each other (Laszlo \& Kripner, 1997; Gupta \& Gupta, 2013). TSSP replicates the principles in System Theory because TSSP is an intergration of all dimensions and elements. Therefore, if any of the components of TSSP doesn't play its role, then, the expected output will be affected.

Recent studies on the dimensions of TSSP such as school leadership, curriculum management, students' development and, parents and community involvement show that these dimensions have a positive relationship with students' academic development (Ismail et al., 2018) . In fact, the Board of Inspectorates \& Quality Assurance (JNJK, 2016) also called for all the standards to be planned as best as possible because it has a positive impact on school excellence in general and students' holistic development in particular.

However, till date we cannot assume the level of TSSP effectiveness on students' academic performance since there isn't any validated instruments available to measure the relationship of these two variables. On that point, there is a need to come up with a measurement instrument which can measure the effectiveness of TSSP on targeted outcome factors.

\section{Methodology}

This study was conducted using a descriptive design aimed to identify the level of validity and reliability of the Trust School Standard and Practices measurement instrument. The sample of this study was 100 teachers as recommended by (Hair, 2010). These teachers were selected 
using from three Trust Schools in Perak and Terengganu purposive sampling. The purpose of using purposive sampling method was to ensure that only teachers with respective criterias were chosen. As for the experts, six of them were appointed to test the level of validity of the instrument. All of them have expertise in the research area and possess a Master and PhD Degree in related field.

The development of this measurement instrument focused on the four dimensions of TSSP; developing high quality leadership and management, improving the quality of learning and teaching, maximizing students' potential and achievement and, strengthening the involvement of parents, community and other stakeholders. It involved several stages such as identifying the dimensions of the instrument, reviewing, and referring to existing instruments related to the dimensions to determine appropriate items. Selection of items were also made based on the literature reviewed.

Validity is an important factor to consider when constructing or selecting an instrument. It refers to the appropriateness, accuracy and applicability of an instrument. The validity conducted in this study refers to the extent of what an instrument supposed to measure. Meanwhile, content validity refers to the extent to which the items of an instrument truly represent the dimensions it seeks to measure. The method of validity testing also adopts the views of Konting (2004) who suggested that the idea of having external evaluators who are experts in the field of study is to ensure that the items in the instrument represent the study. Cresswell (2007) also suggested that researchers should refer to experts in their study field to validate the items or questions of an instrument. On that account, the validity of the Trust School Standards and Practice measurement instrument accomplished by taking the views of six panel experts who have expertise, experience and knowledge in the field studied. This is in line with Lynn (1986) who proposed that at least five experts are required to evaluate the content validity of an instrument.

According to Lynn (1986), for content validity, an instrument requires at least five experts to make assessment and validation. Therefore, this measurement instrument was relevant as it involved six panel experts as evaluators. The evaluation was performed using the I-CVI method or Itemised Content Validity Index.

Expert evaluation form was given to the six panel experts to evaluate all the items in the instrument. The expert evaluation form used a 4 measurement scales; 1 (Not Relevant), 2 (Less Relevant), 3 (Relevant) and 4 (Highly Relevant) to calculate the Content Validity Index for each item based on suggestions made by Martuza (1977), Polit \& Beck ( 2006) and Lynn (1986). To obtain the I-CVI value, the researcher will sum up the scores given by each expert and divide the value with the number of experts as illustrated below:

D (Total Score)

$A+B+C+D+E+F$ (Number of Experts)

\section{Diagram 1. I-CVI Calculation Formula}

Table 1. Interpretation of I-CVI assessment score

\begin{tabular}{|r|r|}
\hline Definition & Score \\
\hline Irrelevant & 1 \\
\hline Less Relevant & 2 \\
\hline Relevant & 3 \\
\hline Highly Relevant & 4 \\
\hline
\end{tabular}


The result from the calculation has shown that the I-CVI value for each item is above 0.80 whilst the $\mathrm{S}-\mathrm{CVI}$ value is 0.90 which indicates the instrument items are excellent.

After conducting expert validation, a pilot study was conducted to test the reliability of the instruments. Reliability refers to the consistency and stability of the instrument (Cohen \& Swerdik, 2010). The number of respondents involved in this study was 100 Trust School teachers from two schools in Perak and one school in Terengganu. There are two parts in this instrument; Part A and Part B. Part A deals with the background of the respondents such as gender, age, academic qualifications, and teaching experience in Trust School. On the other hand, Part B contains statements related to teachers' perceptions on the aspects of leadership, teaching and learning, students' potential and achievement as well as parental and community involvement.

The scale used is a 5 -point Likert scale starting from the No. 1 Strongly Disagree until No. 5 for Strongly Agree. A pilot study was conducted to determine the reliability of the Trust School Standard and Practice Questionnaire by performing Cronbach Alpha internal consistency analysis to assess the level of reliability of each construct. Reliability refers to the consistency of an answer or score provided by an instrument. The scores obtained can be considered reliable but are not necessarily valid. Thus, an instrument of a research must be reliable and valid. Cronbach Alpha is the most commonly used method to measure the items reliability.

\section{Data Analysis}

\section{Validity of the Questionnaire}

The following are the results of the content validity scores obtained from 6 panel experts. The table below shows the I-CVI scores for each item and the S-CVI score: 
INTERNATIONAL JOURNAL OF ACADEMIC RESEARCH IN BUSINESS AND SOCIAL SCIENCES Vol. 12, No. 1, 2022, E-ISSN: 2222-6990 @ 2022 HRMARS

Table 2. I-CVI and S-CVI Score

Item No.

S-CVI Score

\begin{tabular}{|c|c|}
\hline 1 & 1 \\
\hline 2 & 0.83 \\
\hline 3 & 1 \\
\hline 4 & 1 \\
\hline 5 & 1 \\
\hline 6 & 1 \\
\hline 7 & 1 \\
\hline
\end{tabular}

10

11

\begin{tabular}{|l|l}
\hline 11 & 1 \\
\hline 13 & 1 \\
\hline
\end{tabular}

14

15

16

17

\begin{tabular}{l|l}
18 & 1 \\
\hline 19 & 1
\end{tabular}

\begin{tabular}{|l|l}
\hline 19 & \\
\hline 20 &
\end{tabular}

21

\begin{tabular}{|l|l}
21 \\
\hline 22
\end{tabular}

23

24

25

\begin{tabular}{|l|l}
\hline 26 & 1 \\
\hline 27 & 1
\end{tabular}

\begin{tabular}{|l|l}
\hline 27 & 1 \\
\hline 28 & \\
\hline
\end{tabular}

\begin{tabular}{|l|l}
\hline 29 & 0.66 \\
\hline
\end{tabular}

30

31

32

\begin{tabular}{l|l}
33 & 1 \\
34
\end{tabular}

\begin{tabular}{l|l}
34 & 0.83
\end{tabular}

\begin{tabular}{|l|l}
35 & 0.83 \\
\hline
\end{tabular}

\begin{tabular}{|l|l}
\hline 36 & 1 \\
\hline 37
\end{tabular}

37

\begin{tabular}{|l|l|}
\hline 38 & 1 \\
\hline 39 & 1 \\
\hline 40 & 1 \\
\hline 41 & 1 \\
\hline 42 & 1 \\
\hline 43 & 1 \\
\hline 44 & 0.83 \\
\hline
\end{tabular}


The results show all items in the instrument obtained an I-CVI value above 0.80 except for item No. 29. However, according to Lynn (1986), item with a score of 0.6 is acceptable as long as it is modified and improved to be in line with the context of the component measured. After obtaining the I-CVI score, the next process was to calculate the $\mathrm{S}-\mathrm{CVI}$ score $\mathrm{S}-\mathrm{CVI} / \mathrm{UA}$ is calculated by adding all items with I-CVI equal to 1 divided by the total number of items, while S-CVI/Ave is calculated by taking the sum of the I-CVIs divided by the total number of items. From the calculations made, the $S-C V I$ value obtained for all items was 0.90. Based on these calculations, we can conclude that I-CVI, S-CVI/Ave and S-CVI/UA meet the excellent level, and the scale of this questionnaire has achieved satisfactory level of content validity.

Table 3. Content Validity Achievement Results

\begin{tabular}{llll}
\hline No. & External Experts & $\begin{array}{l}\text { Content Validity } \\
\text { Score }\end{array}$ & Experts' Remark \\
\hline 1 & Expert 1 & $100 \%$ & Accepted \\
2 & Expert 2 & $95.0 \%$ & Accepted \\
3 & Expert 3 & $70.0 \%$ & Accepted \\
4 & Expert 4 & $90.0 \%$ & Accepted \\
5 & Expert 5 & $90.0 \%$ & Accepted \\
6 & Expert 6 & $90.0 \%$ & Accepted \\
\hline
\end{tabular}

The expert evaluation made on this set of instrument items also led to some focused changes in terms of number of items in line with the recommendation given by the panel expert so that this instrument reflects the measured constructs (Norazwa, 2018). The following is the change in the number of questionnaire items for each components measured.

Table 4. Number Of Items By Construct

\begin{tabular}{|c|c|c|}
\hline Construct & $\begin{array}{l}\text { Number of Items Before } \\
\text { Expert Evaluation }\end{array}$ & $\begin{array}{l}\text { Number of Items After } \\
\text { Expert Evaluation }\end{array}$ \\
\hline Leadership & $\underline{12}$ & $\underline{8}$ \\
\hline Teaching and Learning & $\underline{19}$ & $\underline{19}$ \\
\hline $\begin{array}{l}\text { Students' Potential and } \\
\text { Achievement }\end{array}$ & $\underline{7}$ & $\underline{7}$ \\
\hline $\begin{array}{l}\text { Parents and Community } \\
\text { Involvement }\end{array}$ & $\underline{6}$ & $\underline{5}$ \\
\hline
\end{tabular}


From the table above, it can be seen that there was a reduction of items after the expert evaluation was conducted. At the initial stage, a total of 44 items were constructed to represent the four TSSP constructs. Yet, after expert evaluation has been done, the number of items was reduced to 39. However, the constructs represented by at least 4 items are sufficient to describe a construct (Harvey, Billings \& Nilan, 1985: Hinkin \& Schriesheim, 1989) as long as the measurement item is capable to describe the constructs measured (Azwa, 2018).

Based on the results of the validity test conducted, the items of this instrument are suitable enough to represent the measured variables in this study. Each panel expert has confirmed that the domains contained in the Trust School Standard Measurement Instrument and Practice clearly represent the studied variables. Therefore, this measurement Instruments is proven and relevant to measure TSSP dimensions.

\section{Trust School Standard and Practices Reliability Result}

The analysis performed to test the reliability is based on the reliability index. Reliability refers to level of consistency of instruments in a construct (Hair et al., 2014). This is in line with the recommendation put forward by Hair et al (2014); Pallant (2011) who emphasized that Cronbach Alpha is the most widely accepted indicator of internal consistency. Hence, data from the questionnaires were analyzed using IBM SPSS version 23.0 software to determine the level of reliability of the questionnaire items through internal consistency method. According to Chua (2006), Cronbach's Alpha reliability coefficient is the most commonly used test used to calculate the reliability of an instrument to prove the reliability of an instrument.

From the analysis performed, the reliability values for this instrument are as follow:

Table 5. Reliability Analysis

\begin{tabular}{|c|c|c|}
\hline Constructs & Number of Items & Cronbach Alpha Value \\
\hline Leadership & 7 & 0.95 \\
\hline Teaching and Learning & 8 & 0.94 \\
\hline $\begin{array}{l}\text { Students' Potential and } \\
\text { Achievement }\end{array}$ & 10 & 0.92 \\
\hline \multicolumn{3}{|l|}{$\frac{\text { Parents and Community }}{\text { Involvement }}$} \\
\hline $\begin{array}{l}\text { According to the } \\
\text { mponent } 1 \text {, Leadership is } 0.9 \\
\text { is high. Likewise, for Compo } \\
0.94 \text {. The item reliability fo } \\
0 \text { high at } 0.92 \text {. Lastly, the }\end{array}$ & $\begin{array}{l}\text { tatistical analysis } \\
\text { This value indicat } \\
\text { comt } 2 \text {, Teaching anc } \\
\text { alue for Compon }\end{array}$ & $\begin{array}{l}\text { d, reliability index va } \\
\text { e item reliability for Com } \\
\text { the reliability index is a } \\
\text { tial and Student Achieve } \\
\text { mely Parental and Com }\end{array}$ \\
\hline
\end{tabular}




\section{Conclusion}

Through a thorough analysis of both validity and reliability of the Trust School Standards and Practice Measurement Instrument, it is deemed that the instrument is extremely valid and reliable. The validity of this instrument has been verified using content validity by panel experts whilst the reliability test using internal consistency Cronbach Alpha. In light of these findings, it is observed that overall alpha values ranged from good to excellent. Therefore, this instrument is suitable to be used to measure the level of effectiveness of TSSP implementation in Trust Schools throughout Malaysia. The findings from the results obtained are expected to be used to improve this programme to achieve the goals as outlined by the Ministry of Education Malaysia.

\section{Acknowledgement}

My utmost appreciation goes to the headmasters of the schools involved in this study for their consent, all respondents who willingly answered this questionnaire and my friend, Dayang Rafidah Syariff M. Fuad for her assistance during data analysis.

\section{Corresponding Author}

\section{Norazila Osman}

Faculty of Management and Economics Universiti Pendididikan Sultan Idris,Tanjung Malim, Perak, Malaysia.

ilaaosman@gmail.com

\section{References}

Ajayi, K. O., \& Oyeniyi, O. L. (2017). Impact of total quality management on students' academic performance in public secondary schools in Ogun State. IFE Psychology: An International Journal, 25(1), 463-480.

Anita P., \& Karanganyar M. I. M. (2019). Peningkatan mutu sekolah melalui Total Quality Management (TQM). Seminar Nasional Pendidikan (SNDIK) I 2019. Surakarta, Indonesia.

Anninos, L. N., \& Chytiris, L. (2011). Searching for excellence in business education. Journal of Management Development approaches. $2^{\text {nd }}$ Edition. Thousand Oaks: Sage.

Ardi, R., Hidayatno, A., \& Zagloel, Y. (2012). Investigating relationships among quality dimensions in higher education. Quality Assurance in Education, 20. 10.1108/09684881211264028.

Bayraktar, E., Tatoglu, E., \& Zaim, S. (2008). An Instrument for measuring the critical factors of TQM in Turkish higher education, Total Quality Management \& Business Excellence, 19(6), $551-57$

Jiménez-Jiménez, D., Martinez-Costa, M., Martínez-Lorente, A. R., \& Rabeh, H. A. D. (2015), Total quality management performance in multinational companies: A learning perspective, The TQM Journal, 27(3), 328-340. https://doi.org/10.1108/TQM-01-20140002

Giannini, M. (2015). Organization and quality in school education. Procedia-Social and Behavioral Sciences, 174(2015), 1735- 1739.

Jiali, H., Yipeng, T., Wenjie, H., \& Qiong, L. (2019) Singapore's School Excellence Model and student learning: evidence from PISA 2012 and TALIS 2013, Asia Pacific Journal of Education, 39(1), 96-112, DOI: 10.1080/02188791.2019.1575185 
Lee, V. H., Ooi, K. B., Tan, B. I., \& Chong, A. Y. L. (2010). A structural analysis of the relationship between TQM practices and product innovation. Asian Journal of Technology Innovation, 18(1), 73-96.

Kamarul B., \& Alnuaimi, A. S. A. (2020). The Impact of Leadership Practices on Total Quality Management and Organizational Performance in the UAE Interior Ministry. European Journal of Multidisciplinary Studies, 5(2), 5-12. https://doi.org/10.26417/ejms.v5i2.p10-15

Osman, N., Yaakub, K. B. (2021). Trust school students' academic performance in Malaysia, Journal of Contemporary Social Science \& Education Studies, 1(2), 106-115

Meera, N. S. (2015). Quality education for all? A case study of a New Delhi government school. Policy Futures in Education, 13(3), 360-374.

Prabhakar, G. V., \& Yaseen, A. (2016). Decision-making styles and leadership: evidences from the UAE. International Journal of Management Development, 1(4), 287-306

Quinn, A., Lemay, G., Larsen, P., \& Johnson, D. M. (2009). Service quality in higher education. Total Quality Management, 20(2), 139-152.

Saiti, A. (2012). Leadership and quality management. Quality Assurance in Education.

Sallis, E. (2001), Total Quality Management in Education (3 ${ }^{\text {rd }}$ ed.), Kogan Page, London.

Sfakianaki, E. (2019). A measurement instrument for implementing total quality management in Greek primary and secondary education. International Journal of Educational Management. 33. 00-00. 10.1108/IJEM-08-2018-0245.

Kumar, V., \& Sharma, R. R. K. (2018). Leadership styles and their relationship with TQM focus for Indian firms: An empirical investigation, International Journal of Productivity and Performance Management, 67(6), 1063-1088, https://doi.org/10.1108/IJPPM-03-20170071 